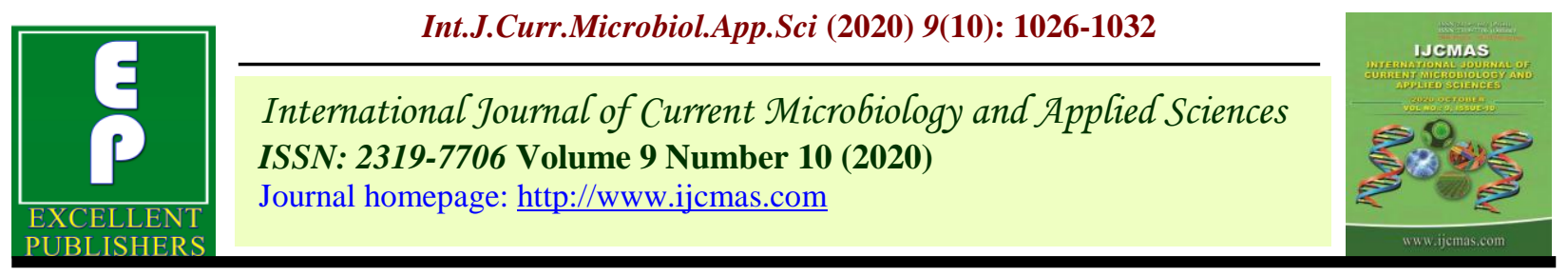

Original Research Article

https://doi.org/10.20546/ijcmas.2020.910.123

\title{
Assessment of Antimicrobial Activity of Underutilized Fruits (Aonla, Bael, Ber, Jackfruit and Kaitha)
}

Anil Kumar ${ }^{*}$ Pratibha Singh, Rudra Pratap Singh and Raj Narayan Kewat

Department of Biochemistry, N.D. University of Agriculture and Technology, Kumarganj, Faizabad, Uttar Pradesh, India

*Corresponding author

\section{A B S T R A C T}

Keywords

Alternaria

brassicae,

antimicrobial

activity, Aspergillus

niger, Pencillium

notatum and

Underutilized fruits

Article Info

Accepted:

10 September 2020

Available Online:

10 October 2020
Antimicrobial activity of radial growth of mycelium of Aspergillus niger, Alternaria brassicae and Pencillium notatum in five fruit pulps viz. Aonal (NA-6 and NA-7), Bael (NB-5 and NB-9), Ber (Karaka and Umran), Jackfruit (NJ-2 and NJ-3) and Kaitha (K-1 and K-2). However all the five fruit pulps at $40 \%$ concentration showed maximum inhibition compared to other tested concentrations. The present study indicated that Aonla fruits extract reduced the growth of Aspergillus niger, Alternaria brassicae and Pencillium notatum at (10, 20, 30 and 40\%) concentrations as compared to control within 10 days after incubation. Antimicrobial activity of five edible pulp of minor fruit germplasms resulted that Aonla fruits extract was recorded highest antimicrobial activity as compared to other tested fruit extracts.

\section{Introduction}

India is a fascinating country in its fruit wealth where almost all fruits that are consumable to human beings are grown. Quite a considerable number of fruit crops have now been existent and large number are still there which are not cropped in organized plantations. These fruit crops which grow here less-exploited or minor fruit crops beyond doubt, contribute a substantial part of the country's fruit production (Majumdar and Daya, 2004). There are several fruits are present in nature which is also nutritionally important and superior in quality but are rarely used by human. People are not aware of its nutritional importance, these fruits are known as underutilized fruits viz., Ber, Bael, Aonla, Kaitha, Jackfruit, Karonda, Imli etc. The product preparations from these fruits can be nutritionally, economically as well as medicinally important. Several compounds are present in fruit like antioxidant, some phenolic compounds, some enzymes as catalases, peroxidases, pectin methylesterase, cellulase, superoxide dismutases etc. 
Anthocyanin and phenolics rich fruits like Jamun and Bael are good source of dietary antioxidants (Kaur and Kapoor, 1998). Aegle marmelos was screened for its antimicrobial activity using disc diffusion method and tested against four gram positive bacteria (Staphylococcus aureus, Staphylococcus epidermidis, Bacillus cereus and Bacillus subtilis), three gram negative bacteria (Escherichia coli, Pseudomonas aeruoginosa and Klebsiella pneumonia) and against three fungi (Aspergillus niger, Aspergillus fumigates and Candida albicans). It was observed that alcoholic leaf extracts showed antibacterial and antifungal activity. The antimicrobial activities of the alcoholic leaf extracts are discussed according to their phytochemical components (Umadevi et al., 2011).

These fruits are grown in Northern India as well as in Eastern Uttar Pradesh also. Aonla fruit is highly nutritive with a great medicinal use and the richest source of vitamin $\mathrm{C}$. It contains 500-1500 mg of ascorbic acid per $100 \mathrm{~g}$ of pulp (Chauhan et al., 2005). Essential oil extracted from kaitha or wood apple was found to possess antimicrobial activity against 12 human pathogenic bacteria (Geda and Bokadia, 1980). Jackfruit contains vitamin $A$, vitamin $C$, thiamin, riboflavin, calcium, potassium, iron, sodium, zinc, and niacin among many other nutrients. Jackfruit has a low caloric content: $100 \mathrm{~g}$ of jackfruit only contains 94 calories (Mukprasirt and Sajjaanantakul 2004).

\section{Materials and Methods}

The experiment was carried out in five underutilized fruits germplasms/varieties namely Aonla $\left(\mathrm{NA}_{6}\right.$ and $\left.\mathrm{NA}_{7}\right)$, Bael $\left(\mathrm{NB}_{5}\right.$ and $\left.\mathrm{NB}_{9}\right)$, Ber (Karaka and Umran), Jackfruit $\left(\mathrm{NJ}_{2}\right.$ and $\left.\mathrm{NJ}_{3}\right)$ and Kaitha $\left(\mathrm{K}_{1}\right.$ and $\left.\mathrm{K}_{2}\right)$ were collected from Horticulture Nursery. The samples were used to assess the antimicrobial activity. Selected fruits were washed with sterilized distilled water, air dried and grinded into powder form for preparation of extract. Aqueous plant extract was prepared by macerating powdered plant sample with $50 \mathrm{ml}$ sterile distilled water. The macerate was filtered and filtrate was centrifuged at 1500 rpm for 15 minutes. Supernatant obtained after centrifugation was heat sterilized at 120 ${ }^{0} \mathrm{C}$ for 30 minutes. Potato Dextrose Agar (PDA) Media was prepared by using $200 \mathrm{gm}$ of potato slices were boiled with distilled water.

The potato infusion was used as water source of media preparation. $20 \mathrm{gm}$ of dextrose was mixed with potato infusion. $20 \mathrm{gm}$ of agar was added as a solidifying agent (Singh et al, 2014). These constituents were mixed and autoclaved. 5-mm culture discs of Aspergillus niger, Alternaria brassicae and Penicillium notatum were taken from ten days old colony and placed in the centre of the Petri dishes containing potato dextrose agar with plant extracts and without extract medium Petri dishes $(90 \mathrm{~mm})$ used as control. The plates with wells were used for antifungal studies. All the plates were incubated at $27^{\circ} \mathrm{C}$ for 7 days and then the diameter of zone of inhibition was noted.

\section{Results and Discussion}

Antimicrobial activity of minor fruits viz. Aonla, Bael, Ber, Jackfruit and Kaitha were given in Table 1 and resulted a slight variation within two germplasm of each fruit pertaining to radial growth of mycelium of Aspergillus niger. The range of variability in selected two germplasm of five fruits viz. Aonal (NA-6 and NA-7), Bael (NB-5 and NB-9), Ber (Karaka and Umran), Jackfruit (NJ-2 and NJ-3) and Kaitha (K-1 and K-2). Extracts of all ten germplasm of five tested fruits inhibited mycelial growth of Aspergillus niger at all the tested concentrations. 


\begin{tabular}{|c|c|c|c|c|c|c|c|c|c|c|c|}
\hline \multirow{3}{*}{$\begin{array}{c}\text { Sl. } \\
\text { No. }\end{array}$} & \multirow[t]{3}{*}{ Fruits } & \multicolumn{10}{|c|}{ Table.1 Radial growth of mycelium of Aspergillus niger (mm) } \\
\hline & & \multicolumn{5}{|c|}{ Concentration (\%) pulp of fruit (2013-14) } & \multicolumn{5}{|c|}{ Concentration (\%) pulp of fruit (2014-15) } \\
\hline & & 10 & 20 & 30 & 40 & Mean & 10 & 20 & 30 & 40 & Mean \\
\hline 1 & NA-6 (Narendra Aonla-6) & 55.33 & 45.66 & 36.40 & 23.66 & 40.26 & 56.49 & 45.69 & 36.40 & 23.67 & 40.56 \\
\hline 2 & NA-7 (Narendra Aonla-7) & 53.33 & 44.66 & 35.40 & 23.33 & 39.18 & 54.28 & 46.52 & 34.61 & 23.30 & 39.68 \\
\hline 3 & NB-5 (Narendra bael-5) & 63.35 & 49.33 & 43.66 & 35.66 & 48.00 & 64.43 & 49.35 & 43.58 & 35.63 & 48.25 \\
\hline 4 & NB-9 (Narendra bael-9) & 65.55 & 50.33 & 45.60 & 36.33 & 49.45 & 66.52 & 50.42 & 45.52 & 36.40 & 49.72 \\
\hline 5 & Ber K- Ber (Karaka) & 70.55 & 65.33 & 59.50 & 43.33 & 59.67 & 71.68 & 65.62 & 59.48 & 43.52 & 60.08 \\
\hline 6 & Ber U-Ber (Umran) & 71.33 & 64.55 & 58.33 & 45.50 & 59.92 & 72.45 & 64.41 & 58.35 & 45.39 & 60.15 \\
\hline 7 & NJ-2 (Narendra Jackfruit-2) & 79.66 & 72.50 & 66.33 & 61.50 & 69.99 & 80.55 & 72.52 & 66.40 & 61.55 & 70.26 \\
\hline 8 & NJ-3 (Narendra Jackfruit-3) & 81.50 & 71.33 & 67.33 & 62.66 & 70.70 & 82.53 & 71.37 & 67.39 & 62.41 & 70.93 \\
\hline 9 & K-1 (Kaitha-1) & 58.35 & 45.33 & 40.66 & 30.66 & 43.75 & 59.33 & 45.38 & 40.50 & 30.61 & 70.96 \\
\hline 10 & K-2 (Kaitha-2) & 57.88 & 46.55 & 39.33 & 28.66 & 43.10 & 58.72 & 46.61 & 39.28 & 28.58 & 43.30 \\
\hline 11 & Control & 90.00 & 90.00 & 90.00 & 90.00 & 90.00 & 90.00 & 90.00 & 90.00 & 90.00 & 90.00 \\
\hline
\end{tabular}

\begin{tabular}{|c|c|c|c|c|c|c|c|c|c|c|c|}
\hline \multirow{3}{*}{$\begin{array}{l}\text { Sl. } \\
\text { No. }\end{array}$} & \multirow[t]{3}{*}{ Fruits } & \multicolumn{10}{|c|}{ Table.2 Radial growth of mycelium of Alternaria brassicae (mm) } \\
\hline & & \multicolumn{5}{|c|}{ Concentration (\%) pulp of fruit $(2013-14)$} & \multicolumn{5}{|c|}{ Concentration (\%) pulp of fruit (2014-15) } \\
\hline & & 10 & 20 & 30 & 40 & Mean & 10 & 20 & 30 & 40 & Mean \\
\hline 1 & NA-6 (Narendra Aonla-6) & 59.60 & 49.33 & 40.55 & 28.75 & 44.55 & 59.55 & 49.61 & 40.45 & 28.70 & 44.58 \\
\hline 2 & NA-7 (Narendra Aonla-7) & 58.33 & 47.55 & 38.60 & 27.33 & 42.95 & 57.35 & 47.50 & 38.55 & 27.37 & 42.69 \\
\hline 3 & NB-5 (Narendra bael-5) & 65.38 & 53.33 & 49.25 & 38.56 & 51.63 & 65.41 & 53.37 & 49.30 & 38.61 & 51.68 \\
\hline 4 & NB-9 (Narendra bael-9) & 68.33 & 54.88 & 49.70 & 39.33 & 53.06 & 68.40 & 54.82 & 49.65 & 39.25 & 53.03 \\
\hline 5 & Ber K- Ber (Karaka) & 75.33 & 67.80 & 60.40 & 48.63 & 63.04 & 76.32 & 67.75 & 60.45 & 48.67 & 63.30 \\
\hline 6 & Ber U-Ber (Umran) & 74.55 & 67.55 & 61.03 & 48.66 & 62.94 & 74.60 & 67.60 & 61.10 & 48.70 & 63.00 \\
\hline 7 & NJ-2 (Narendra Jackfruit-2) & 83.76 & 75.40 & 68.33 & 66.33 & 73.45 & 83.70 & 75.45 & 68.25 & 66.39 & 73.45 \\
\hline 8 & NJ-3 (Narendra Jackfruit-3) & 83.80 & 74.33 & 69.25 & 65.66 & 73.26 & 84.50 & 74.38 & 69.30 & 65.50 & 73.42 \\
\hline 9 & K-1 (Kaitha-1) & 64.30 & 49.40 & 43.45 & 33.55 & 47.67 & 64.67 & 49.45 & 43.41 & 33.49 & 47.76 \\
\hline 10 & K-2 (Kaitha-2) & 61.40 & 49.65 & 42.66 & 30.45 & 46.04 & 61.45 & 49.70 & 42.55 & 30.40 & 46.03 \\
\hline 11 & Control & 90.00 & 90.00 & 90.00 & 90.00 & 90.00 & 90.00 & 90.00 & 90.00 & 90.00 & 90.00 \\
\hline
\end{tabular}




\begin{tabular}{|c|c|c|c|c|c|c|c|c|c|c|c|}
\hline \multirow{3}{*}{$\begin{array}{l}\text { Sl. } \\
\text { No. }\end{array}$} & \multirow[t]{3}{*}{ Fruits } & \multicolumn{10}{|c|}{ Table.3 Radial growth of mycelium of Pencillium notatum (mm) } \\
\hline & & \multicolumn{5}{|c|}{ Concentration (\%) edible pulp of fruit (2013-14) } & \multicolumn{5}{|c|}{ Concentration (\%) edible pulp of fruit (2014-15) } \\
\hline & & 10 & 20 & 30 & 40 & Mean & 10 & 20 & 30 & 40 & Mean \\
\hline 1 & NA-6 (Narendra Aonla-6) & 62.35 & 53.45 & 44.75 & 31.33 & 47.97 & 62.30 & 53.40 & 44.20 & 31.35 & 47.81 \\
\hline 2 & NA-7 (Narendra Aonla-7) & 63.10 & 53.33 & 45.11 & 31.35 & 48.22 & 63.15 & 53.28 & 45.06 & 31.41 & 48.23 \\
\hline 3 & NB-5 (Narendra bael-5) & 67.33 & 55.60 & 52.25 & 39.33 & 53.63 & 67.37 & 55.65 & 52.28 & 39.37 & 53.67 \\
\hline 4 & NB-9 (Narendra bael-9) & 67.66 & 56.33 & 52.10 & 40.25 & 54.09 & 67.61 & 56.36 & 52.15 & 40.20 & 54.08 \\
\hline 5 & Ber K- Ber (Karaka) & 77.33 & 68.65 & 62.35 & 49.20 & 64.38 & 77.37 & 68.58 & 62.40 & 49.25 & 64.40 \\
\hline 6 & Ber U-Ber (Umran) & 77.66 & 68.33 & 61.90 & 49.68 & 64.39 & 77.69 & 68.28 & 61.95 & 49.72 & 67.07 \\
\hline 7 & NJ-2 (Narendra Jackfruit-2) & 85.90 & 76.33 & 69.40 & 60.33 & 72.99 & 85.95 & 76.36 & 69.35 & 60.36 & 73.01 \\
\hline 8 & NJ-3 (Narendra Jackfruit-3) & 86.90 & 76.68 & 69.70 & 60.66 & 73.49 & 86.96 & 76.62 & 69.75 & 60.70 & 73.51 \\
\hline 9 & K-1 (Kaitha-1) & 65.66 & 52.00 & 49.00 & 40.33 & 51.75 & 65.61 & 52.55 & 49.06 & 40.31 & 51.88 \\
\hline 10 & K-2 (Kaitha-2) & 66.33 & 52.33 & 48.66 & 41.10 & 52.11 & 66.38 & 52.38 & 48.70 & 41.15 & 52.15 \\
\hline 11 & Control & 90.00 & 90.00 & 90.00 & 90.00 & 90.00 & 90.00 & 90.00 & 90.00 & 90.00 & 90.00 \\
\hline
\end{tabular}


Data revealed that extract of aonla showed maximum mycelial growth inhibition of Aspergillus niger at 10, 20, 30 and 40 per cent pulp concentration were recorded (53.33 and 55.33, 44.66 and 45.66, 35.40 and 36.40 and 23.66 and $23.33 \mathrm{~mm}$ ) followed by Kaitha extract (57.88 and 58.35, 45.33 and 46.55, 39.33 and 40.66 and 28.66 and $30.66 \mathrm{~mm}$ ) and Bael (63.35 and 65.55, 49.33 and 50.33, 43.66 and 45.60 and 35.66 and $36.33 \mathrm{~mm}$ ). Ber extract (70.55 and 71.33, 64.55 and 65.33, 58.33 and 59.50 and 43.33 and 45.50 $\mathrm{mm})$ also inhibited its mycelial growth followed by jackfruits extract (79.66 and $81.50,71.33$ and $72.50,66.33$ and 67.33 and 61.50 and $62.66 \mathrm{~mm}$ ) as compared to control. However all the five fruit pulps at $40 \%$ concentration showed maximum inhibition compared to other tested concentrations. The present study indicated that Aonla fruits extract reduced the growth of Aspergillus niger at (10, 20, 30 and 40\%) concentrations as compared to control within 10 days after incubation. Patil et al., (2012) reported that extracts of aonla was found most effective against Aspergillus niger as compared to other tested extracts. Similar results on the efficacy of four fresh fruits of Malus domestica, Punica granatum, Psidium guajava, and Citrus sinenses fruit extracts against Aspergillus sp. have been reported by (Malaviya and Mishra 2011).

Antimicrobial activity of minor fruits viz. Aonla, Bael, Ber, Jackfruit and Kaitha were given in Table 2 and resulted a slight variation within two germplasm of each fruit pertaining to radial growth of mycelium of Alternaria brassicae. The range of variability in selected two germplasm of five fruits viz. Aonal (NA-6 and NA-7), Bael (NB-5 and NB-9), Ber (Karaka and Umran), Jackfruit (NJ-2 and NJ-3) and Kaitha (K-1 and K-2). Extracts of all ten germplasm of five tested fruits inhibited mycelial growth of Alternaria brassicae at all the tested concentrations. Data revealed that extract of aonla showed maximum mycelial growth inhibition of Alternaria brassicae at 10, 20, 30 and 40 per cent pulp concentration were recorded (58.33 and 59.60, 47.55 and 49.33, 38.60 and 40.55 and 27.33 and $28.75 \mathrm{~mm}$ ) followed by Kaitha extract (61.40 and 64.30, 49.40 and 49.65, 42.66 and 43.45 and $30.4533 .55 \mathrm{~mm}$ ) and Bael (65.38 and 68.33, 53.33 and 54.88, 49.25 and 49.70 and 38.56 and $39.33 \mathrm{~mm}$ ). Ber extract (74.55 and $75.33,67.55$ and 67.80 , 60.40 and 61.03 and 48.63 and $48.66 \mathrm{~mm}$ ) also inhibited its mycelial growth followed by jackfruits extract (83.76 and 83.80, 74.33 and $75.40,68.33$ and 69.25 and 65.66 and $66.33 \mathrm{~mm}$ ) as compared to control. However all the five fruit pulps at $40 \%$ concentration showed maximum inhibition compared to other tested concentrations. The present study indicated that Aonla fruits extract reduced the growth of Alternaria brassicae at (10, 20, 30 and $40 \%$ ) concentrations as compared to control within 10 days after incubation. Patil et al., (2012) studied that the different solvent extracts of E. officinalis shown to have antibacterial activity against commonly encountered pathogens. Das et al., (2012) also found that antibacterial activity against tested gram positive and gram negative bacteria when compared with standard antibiotics. Study suggests that the ripe fruits of Aegle marmelos are promising in the development of phytomedicine for antimicrobial properties. Madhavi et al., (2013) assess the potential antimicrobial activity of methanolic, ethanolic and chloroform extracts of fruit latex of Artocarpus heterophyllus against different pathogenic bacteria and fungus. Ponnuraj et $a l$. , (2015) analyzed that the phytochemical composition using spectral analysis and antibacterial activity of Limonia acidissima fruit methanol extract. The variation in inhibition among test extracts could be due to variation in the components of antifungal chemicals in different fruit extracts. 
Antimicrobial activity of minor fruits viz. Aonla, Bael, Ber, Jackfruit and Kaitha were given in Table 3 and resulted a slight variation within two germplasm of each fruit pertaining to radial growth of mycelium of Pencillium notatum. The range of variability in selected two germplasm of five fruits viz. Aonal (NA-6 and NA-7), Bael (NB-5 and NB-9), Ber (Karaka and Umran), Jackfruit (NJ-2 and NJ-3) and Kaitha (K-1 and K-2). Extracts of all ten germplasm of five tested fruits inhibited mycelial growth of Pencillium notatum at all the tested concentrations. Data revealed that extract of aonla showed maximum mycelial growth inhibition of Pencillium notatum at 10, 20, 30 and 40 per cent pulp concentration were recorded (62.35 and 63.10, 53.33 and 53.45, 44.75 and 45.11 and 31.33 and $31.35 \mathrm{~mm}$ ) followed by Kaitha extract (65.66 and 66.33, 52.00 and 52.33, 48.66 and 49.00 and 40.33 and $41.10 \mathrm{~mm}$ ) and Bael (67.33 and 67.66, 55.60 and 56.33, 52.10 and 52.25 and 39.33 and $40.25 \mathrm{~mm}$ ). Ber extract (77.33 and 77.66, 68.33 and $68.65,61.90$ and 62.35 and $49.2049 .68 \mathrm{~mm}$ ) also inhibited its mycelial growth followed by jackfruits extract (85.90 and 86.90, 76.33 and $76.68,69.40$ and 69.70 and 60.33 and 60.66 $\mathrm{mm}$ ) as compared to control. However all the five fruit pulps at $40 \%$ concentration showed maximum inhibition compared to other tested concentrations. The present study indicated that Aonla fruits extract reduced the growth of Pencillium notatum at (10, 20, 30 and 40\%) concentrations as compared to control within 10 days after incubation. Abalaka et al., (2010) evaluated that the antimicrobial activities of two Ziziphus species (Ziziphus mauritiana L. and Ziziphus spinachristi L.) on some microbial pathogens. Ponnuraj et al., (2015) analyzed that the spectroscopic and antibacterial efficacy of bioactive compounds from limonia acidissima. fruit extract against clinical pathogens. Madhavi et al., (2013) Studied on phytochemical analysis and antimicrobial activity of Artocarpus heterophyllus fruit latex against selected pathogenic microorganisms. The variation in inhibition among test extracts could be due to variation in the components of antifungal chemicals in different fruit extracts.

\section{References}

Abalaka, M. E., Daniyan, S. Y. and Mann, A. 2010. Evaluation of the antimicrobial activities of two Ziziphus species (Ziziphus mauritiana L. and Ziziphus spinachristi L.) on some microbial pathogens. Afr. J. Pharm. Pharmacol, 4(4):135-139.

Chauhan, O. P., Srivastava S., Pandey P, Rai G. K. 2005. A study on the Development of Aonla Blended Sauce. Beverage Food World, 32(5): 31-32.

Das, S., Sarkar, A., Seth, A., Gupta, N. and Agrawal, R. C. 2012. Evaluation of in-vitro antibacterial potential of ripe fruits of Aegle marmelos. Int. J. Pharm. Sci, 4(3): 179-181.

Geda, A., Bokadia, M. M. 1980. Antimicrobial activity of essential oils on human pathogenic bacteria. Science \& Culture, 46(1), 33-35.

Kaur, C and Kapoor, A. 1998. Antioxidant activity of some fruits in Indian Diet. $J$. Acta Horti. 2: 696.

Madhavi, Y., Rao, K. V. R., Kiran, C. R. and Rao, T. R. 2013. Studies on phytochemical analysis and antimicrobial activity of Artocarpus heterophyllus fruit latex against selected pathogenic microorganisms. International Journal of Scientific \& Engineering Research, 4(10).

Majumdar, B. C. and Daya, C. 2004. Minor fruit crops of India. Tropical and subtropical. J.Prog. Hort., 146 (81): 7035-7333.

Malaviya, A. and Mishra, N. 2011. Antimicrobial activity of tropical fruits. Biological Forum An International 
Journal, 3(1): 1-4.

Mukprasirt, A. and Sajjaanantakul, K. 2004. Physico-chemical properties of flour and starch from jackfruit seed. Intl $J$ Food Sci Technol, 39(3): 271-6.

Patil, S. G., Deshmukh A. A., Padol, A. R. and Kale, D. B. 2012. In vitro antibacterial activity of Emblica officinalis fruit extract by tube Dilution Method. International J. of Toxicology and Applied Pharmacology, 2(4): 4951.

Ponnuraj, S., Jaganathan, D., Kanagarajan, M. and Deivamarudachalam, T. P. D. 2015. Spectroscopic analysis and antibacterial efficacy of bioactive compounds from limonia acidissima. fruit extract against clinical pathogens. Int J Pharm Pharm Sci., 7(3): 383-389.

Singh, M. and Singh, H. K. 2014. Morphological and Cultural Variability in Alternariabrassicae Isolates of Indian Mustard, Brassica juncea L. Czern\&Coss. In Uttar Pradesh. Trends in Biosciences, 7(20): 3125-3128.

Umadevi, K. J., Vanitha, V. and Vijayalakshmi, K. 2011. Antimicrobial activity of three Indian medicinal plants an in vitro study, An International Quarterly J. of Life Sciences., 6(1): 2528.

\section{How to cite this article:}

Anil Kumar, Pratibha Singh, Rudra Pratap Singh and Raj Narayan Kewat. 2020. Assessment of Antimicrobial Activity of Underutilized Fruits (Aonla, Bael, Ber, Jackfruit and Kaitha). Int.J.Curr.Microbiol.App.Sci. 9(10): 1026-1032. doi: https://doi.org/10.20546/ijcmas.2020.910.123 